September 2003 - NREL/TP-540-34872

\title{
Idle Reduction Technology Demonstration Plan
}

\section{Update}

Ken Proc, National Renewable Energy Laboratory

Bob Nitschke, Idaho National Engineering and Environmental Laboratory

Fred Wagner, Energetics

Mike Anderson, U.S. Department of Energy

Lee Slezak, U.S. Department of Energy

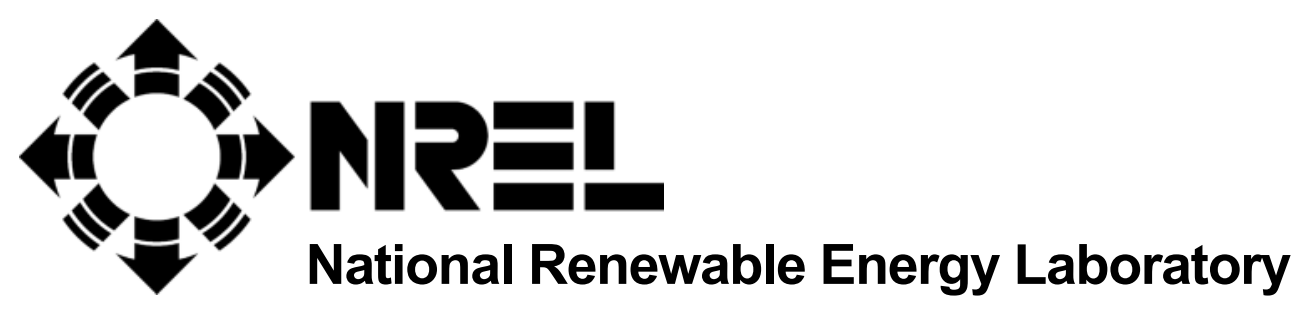

1617 Cole Boulevard

Golden, Colorado 80401-3393

NREL is a U.S. Department of Energy Laboratory

Operated by Midwest Research Institute $\bullet$ Battelle $\bullet$ Bechtel

Contract No. DE-AC36-99-G010337 


\section{Idle Reduction Technology Demonstration Plan}

\section{Update}

Ken Proc, National Renewable Energy Laboratory

Bob Nitschke, Idaho National Engineering and Environmental Laboratory

Fred Wagner, Energetics

Mike Anderson, U.S. Department of Energy

Lee Slezak, U.S. Department of Energy

Prepared under Task No. FY03.0730

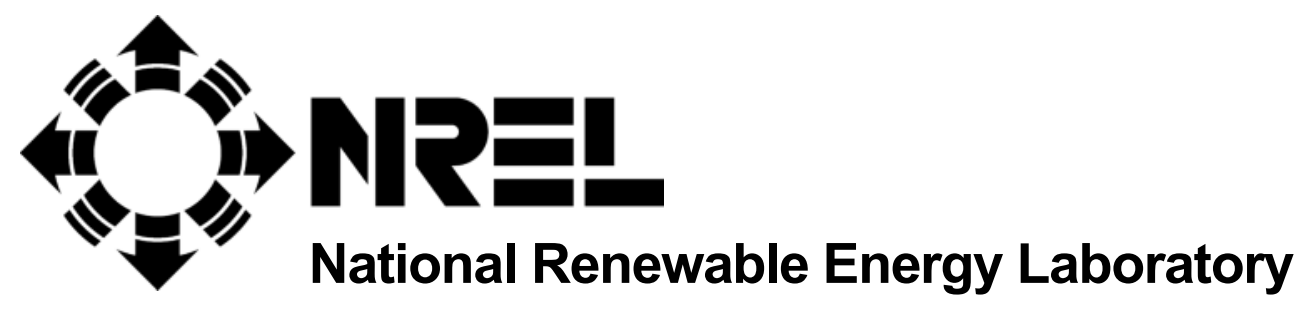

1617 Cole Boulevard

Golden, Colorado 80401-3393

NREL is a U.S. Department of Energy Laboratory

Operated by Midwest Research Institute $\bullet$ Battelle $\bullet$ Bechtel

Contract No. DE-AC36-99-G010337 


\section{NOTICE}

This report was prepared as an account of work sponsored by an agency of the United States government. Neither the United States government nor any agency thereof, nor any of their employees, makes any warranty, express or implied, or assumes any legal liability or responsibility for the accuracy, completeness, or usefulness of any information, apparatus, product, or process disclosed, or represents that its use would not infringe privately owned rights. Reference herein to any specific commercial product, process, or service by trade name, trademark, manufacturer, or otherwise does not necessarily constitute or imply its endorsement, recommendation, or favoring by the United States government or any agency thereof. The views and opinions of authors expressed herein do not necessarily state or reflect those of the United States government or any agency thereof.

Available electronically at http://www.osti.gov/bridge

Available for a processing fee to U.S. Department of Energy

and its contractors, in paper, from:

U.S. Department of Energy

Office of Scientific and Technical Information

P.O. Box 62

Oak Ridge, TN 37831-0062

phone: 865.576.8401

fax: 865.576 .5728

email: reports@adonis.osti.gov

Available for sale to the public, in paper, from:

U.S. Department of Commerce

National Technical Information Service

5285 Port Royal Road

Springfield, VA 22161

phone: 800.553.6847

fax: 703.605.6900

email: orders@ntis.fedworld.gov

online ordering: http://www.ntis.gov/ordering.htm 


\section{Table of Contents}

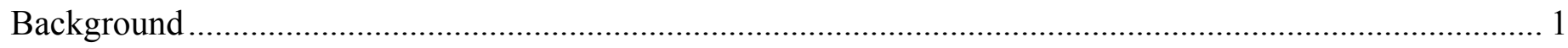

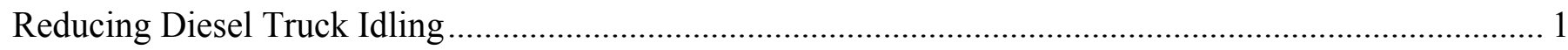

Idle Reduction Technology Status ................................................................................................. 2

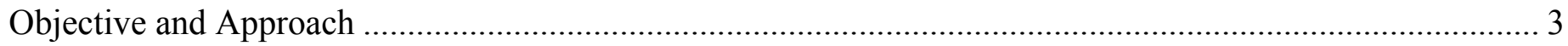

Support for $21^{\text {st }}$ Century Truck Partnership ...................................................................................... 4

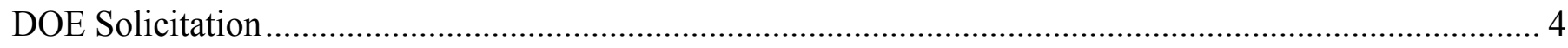

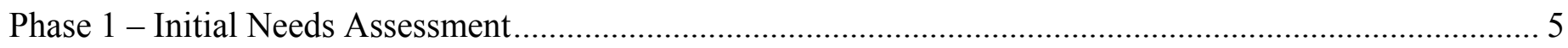

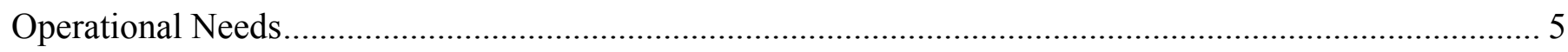

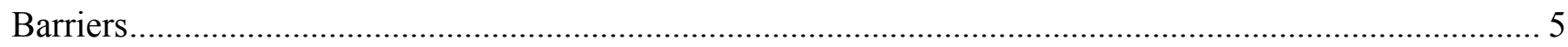

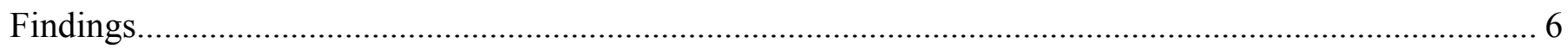

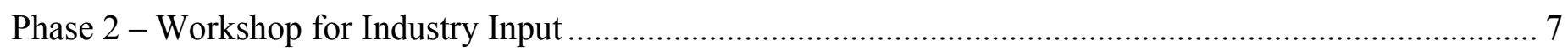

Phase 3 - Solicitation and Award of Demonstration Projects ..................................................................... 7

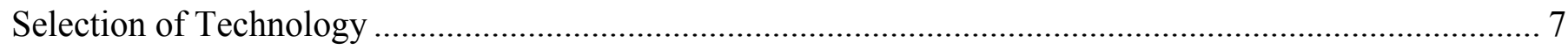

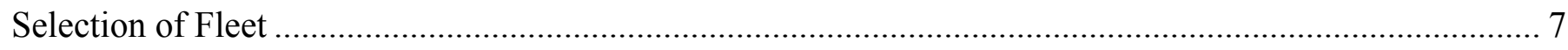

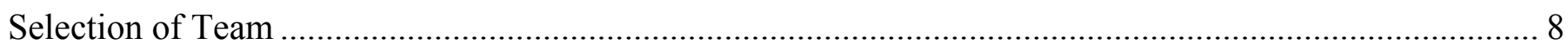

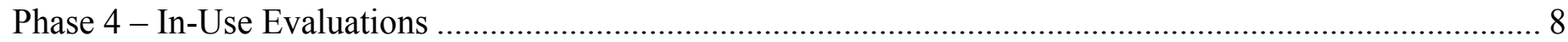

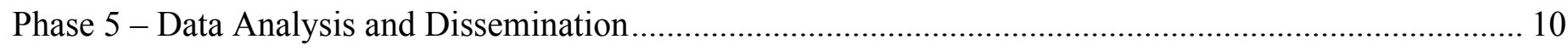

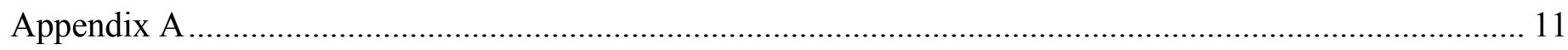

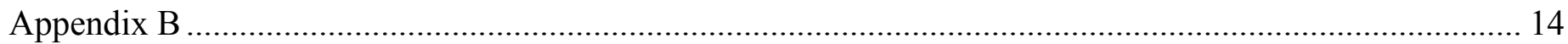




\section{Background}

The U.S. Department of Energy's (DOE) Advanced Vehicle Testing Activity (AVTA) initiated a study of diesel truck engine idle reduction technologies and the needs of the trucking industry for using these technologies to reduce fuel use and emissions. Idle reduction includes methods and technologies that provide alternatives for cabin heating and cooling, maintaining engine and fuel system warmth for easy startup, and providing electricity for other amenities - activities that usually require the truck engine to idle. Idle reduction technology consists of onboard auxiliary units, including direct-fired heaters and auxiliary power units (APUs), and offboard truck stop electrification (TSE) equipment that supply electric power for heating, ventilation, and air conditioning (HVAC).

Even though some analysis indicates a possible two-year payback in fuel savings alone, feedback from preliminary discussions and study results indicates that initial cost is a major, if not the most important factor, for limited market penetration of current idle reduction technologies. Other barriers reported include driver education, training and overall receptiveness, and issues related to reliability and maintenance requirements. The purpose of this Demonstration Plan is to define a pathway to idle reduction technology implementation and use by addressing these issues. The intended outcome of this demonstration and evaluation is to identify and remove barriers for the targeted use of idle reduction technologies in trucking applications. Objective analysis of this evaluation activity will provide truck operators with unbiased information on idle reduction technology upon which they can base their purchasing decisions. Positive results will encourage truck operators to demand these systems and motivate truck manufacturers to integrate and install idle reduction as standard equipment.

\section{Reducing Diesel Truck Idling}

Heavy-duty trucks are excellent candidates for idle reduction technology because many operate at idle $30 \%$ to $50 \%$ or more of the time. An engine in a truck without idle reduction equipment may need to idle to heat or cool the cab. During the winter, the engine may need to be idled to keep the engine, oil, and fuel warm for easier starting. At low temperatures, diesel fuel can gel in the tank and fuel lines, plugging the filter and fuel system.

Diesel engine idling increases fuel consumption, engine wear, and required engine maintenance. The fuel consumption for diesel trucks at idle is typically $0.8-1.5 \mathrm{~g} / \mathrm{hr}$, depending on the engine size, ambient temperature, and load for HVAC and other electrical loads. Idling also causes undesirable emissions. The average emissions for heavy-duty diesel engines are shown in Table 1.

Table 1. Heavy-Duty Diesel Engine Emissions at Idle (g/hr)

\begin{tabular}{|l|r|}
\hline \multicolumn{1}{|c|}{ Emission } & Heavy-Duty Diesel \\
\hline Volatile Organic Compound (VOC) & 12.6 \\
\hline Carbon Monoxide $(\mathrm{CO})$ & 94.6 \\
\hline Oxides of Nitrogen $\left(\mathrm{NO}_{\mathrm{x}}\right)$ & $144^{*}$ \\
\hline Particulate Matter $(\mathrm{PM})$ & 2.57 \\
\hline Carbon Dioxide $\left(\mathrm{CO}_{2}\right)$ & $8,224^{*}$ \\
\hline
\end{tabular}

Sources: Environmental Protection Agency (EPA) Web site: www.epa.gov/OMS/consumer/f98014.htm (April 1998) and

${ }^{*}$ http://www.epa.gov/otaq/retrofit/documents/r02025.pdf (October 2002)

Heavy-duty trucks are typically parked and idled so the driver can rest at truck stops and roadside rest areas instead of checking into a motel. These stops can have hundreds of trucks idling in the parking area at once. Diesel-powered trucks at idle produce noise, vibrations, and emissions that affect drivers, other truck stop or rest area patrons, and neighbors. Many places in the United States (especially metropolitan areas) have laws (not always strongly enforced) that prohibit or restrict the idle time of heavy-duty trucks. 
Truck companies and owner-operators endeavor to comply with these laws, while keeping drivers comfortable, and lowering operating costs.

\section{Idle Reduction Technology Status}

The trucking industry has been using various forms of idle reduction for some time. Many are as simple as enabling the engine control system to shut the engine off if it idles longer than a set length of time. In northern states, some over-the-road trucks have fuel-fired heaters for the cold nights. Special inverter (AC to $\mathrm{DC}$ power) kits that allow the truck to be plugged into an $\mathrm{AC}$ outlet are commercially available. These devices have been used to reduce fuel consumption and save on operating costs in limited applications.

Higher-impact solutions are available to reduce diesel truck idling by providing auxiliary power for heating, cooling, and accessories. But interest in these more sophisticated idle reduction technologies is also limited in the trucking industry. Onboard auxiliary units (such as APUs) have a higher initial cost and add weight, maintenance, and complexity. Electric power provided at parking locations requires new infrastructure and usually requires additional onboard equipment.

A successful implementation of idle reduction technology will require a demonstrated reduction in fuel and other operating costs with minimal equipment costs. Table 2 lists the average truck operations costs for all heavy-duty truck vocations. Further cost reductions could be realized if truck maintenance was reduced by less engine idling - extremely important when considering that the average margin of profit for a trucking firm is $2 \%$ to $3 \%$. In fact, recent analysis by DOE's Argonne National Laboratory (Report ANL/ESD-43, June 2000) has shown significant financial savings opportunities with widespread introduction of more auxiliary power type idle reduction technologies. Although the analysis is positive and encouraging, limited utilization of idle reduction technologies has resulted in a lack of comparative data on the performance of these technologies in operation.

\section{Table 2. Average Truck Operations Cost for All Vocations} (Operating Year 2000)

\begin{tabular}{|l|r|}
\hline \multicolumn{1}{|c|}{ Operating Category } & \multicolumn{2}{c|}{$\begin{array}{c}\text { Percent of Total } \\
\text { Cost }\end{array}$} \\
\hline Wages, Salaries, Fringe & 45.4 \\
\hline Fuel, Oil, Lubrications & 6.2 \\
\hline Maintenance and Supplies & 6.1 \\
\hline Insurance & 2.4 \\
\hline Equipment Costs and Taxes & 20.5 \\
\hline Other Miscellaneous Total & 19.4 \\
\hline \multicolumn{1}{|c|}{ To0.0 } \\
\hline
\end{tabular}

Source: American Trucking Associations (ATA), Motor Carrier Annual Reports 2000, TT Press, 2002

Table 3 lists many commercial products available for idle reduction in trucking. Each technology has an estimated diesel fuel consumption of less than $0.3 \mathrm{~g} / \mathrm{hr}$ (manufacturer data), which is much lower than the $0.8-1.5 \mathrm{~g} / \mathrm{hr}$ fuel consumption of a typical heavy-duty diesel engine at idle. 
Table 3. Summary of Available Idle Reduction Equipment

\begin{tabular}{|c|c|c|c|}
\hline Manufacturer & Model and Type & $\begin{array}{l}\text { Diesel } \\
\text { Gallon/Hour } \\
\text { Consumption }\end{array}$ & $\begin{array}{l}\text { Price Range } \\
\text { Estimate }\end{array}$ \\
\hline \multicolumn{4}{|c|}{ Fuel-Fired Heaters } \\
\hline Espar Heater Systems & $\begin{array}{l}\text { Several models and sizes of fuel-fired } \\
\text { heaters and engine coolant heaters }\end{array}$ & 0.05 & $\$ 1,300-\$ 2,600$ \\
\hline Teleflex Ltd./Proheat & X45 model is only a heater for the cab & 0.1 & $\$ 2,000$ \\
\hline $\begin{array}{l}\text { Webasto Thermosystems, } \\
\text { Inc. }\end{array}$ & $\begin{array}{l}\text { Several models of heaters and coolant } \\
\text { heaters available }\end{array}$ & $0.03-0.24$ & $\$ 1,000-\$ 2,500$ \\
\hline \multicolumn{4}{|c|}{ Auxiliary Power Units } \\
\hline Aura Systems, Inc. & $\begin{array}{l}\text { AuraGen products provide onboard power } \\
\text { generation from the engine or vehicle battery }\end{array}$ & $\begin{array}{l}0 \\
\text { (electric from } \\
\text { engine or } \\
\text { battery) }\end{array}$ & $\$ 7,000$ \\
\hline AUX Generators Inc. & $\begin{array}{l}\text { Two models (AUX power systems and } \\
\text { GENAUX 2000), provide power and HVAC } \\
\text { in cab, uses small Kubota diesel engine }\end{array}$ & 0.3 & $\$ 6,000-\$ 7,000$ \\
\hline Double Eagle Industries & $\begin{array}{l}\text { The Gen-Pac model provides HVAC and } \\
\text { power, uses Kubota diesel engine }\end{array}$ & 0.3 & $\begin{array}{l}\$ 8,500 \text { with air } \\
\text { conditioning }\end{array}$ \\
\hline $\begin{array}{l}\text { Frigette Truck Climate } \\
\text { Systems }\end{array}$ & $\begin{array}{l}\text { Three models provide for HVAC in the cab } \\
\text { and two of those models provide power to } \\
\text { the cab, uses Kubota engine }\end{array}$ & $0.1-0.2$ & $\$ 6,000-\$ 7,500$ \\
\hline Pony Pack, Inc. & $\begin{array}{l}\text { Pony Pack APU provides power and HVAC, } \\
\text { uses Kubota engine }\end{array}$ & 0.2 & $\$ 5,600$ \\
\hline RigMaster Power & $\begin{array}{l}\text { Provides separate HVAC and power to cab, } \\
\text { uses Perkins diesel engine }\end{array}$ & 0.2 & $\$ 5,300$ \\
\hline Teleflex Ltd/Proheat & $\begin{array}{l}\text { Proheat Gen4 provides HVAC and power to } \\
\text { the cab, Kubota engine }\end{array}$ & $0.1-0.3$ & $\$ 5,000-\$ 6,000$ \\
\hline Truck Gen, Inc. & $\begin{array}{l}\text { Provides power generation in } 3.5 \mathrm{~kW} \text { and } \\
5.5 \mathrm{~kW} \text { sizes and APU with power and } \\
\text { HVAC for cab, all three use Kubota engines }\end{array}$ & $0.1-0.2$ & $\$ 5,000-\$ 6,500$ \\
\hline $\begin{array}{l}\text { Willis Auxiliary Power } \\
\text { Dynamics, LLC }\end{array}$ & $\begin{array}{l}\text { APU replaces battery pack so that only one } \\
12 \mathrm{~V} \text { battery is required, provides power and } \\
\text { HVAC to cab, uses Kubota engine }\end{array}$ & 0.25 & $\$ 6,500$ \\
\hline \multicolumn{4}{|c|}{ Truck Stop Electrification } \\
\hline Idle Aire Technologies Corp. & $\begin{array}{l}\text { Provides power, telecommunications, and } \\
\text { HVAC at truck stop as a unit that fits into the } \\
\text { window, two installations on New York } \\
\text { Thruway and one in development in } \\
\text { Tennessee }\end{array}$ & $\mathrm{N} / \mathrm{A}$ & \$9-\$12 per night \\
\hline Phillips & $\begin{array}{l}\text { ElectroLink Kit for the truck to allow } 110 \mathrm{~V} \\
\text { AC plug in with inverter for onboard DC } \\
\text { power }\end{array}$ & $\mathrm{N} / \mathrm{A}$ & $\$ 2,200$ \\
\hline Xantrex & $\begin{array}{l}\text { Kit for the truck to allow } 110 \mathrm{~V} \text { AC plug in } \\
\text { with inverter for onboard DC power }\end{array}$ & $\mathrm{N} / \mathrm{A}$ & $\$ 2,000-\$ 4,000$ \\
\hline
\end{tabular}

(Source: EPA Web site, www.epa.gov/otaq/retrofit/idling.htm)

\section{Objective and Approach}

The goal of this demonstration and evaluation effort is to gather objective in-use information on the performance of available idle reduction technologies by characterizing the cost; fuel, maintenance, and engine life savings; payback; and user impressions of various systems and techniques. The initial step has been to assess the needs and motivation of the trucking industry and independent truck operators to identify technologies that may have the greatest impact on reducing engine idling time and its associated fuel use. Once identified, select idle reduction systems will be installed on truck fleets of various sizes and geographic locations and monitored for in-use performance. The data collected will be used to 
identify and develop solutions to widespread implementation. All information and reports of technology performance will be shared with interested parties to encourage and facilitate the use of idle reduction.

Previous studies and analyses have shown some operational cost and emission reduction potential by reducing truck idling through existing technologies, but there are limited published in-use data on currently available idle reduction technologies that quantify these potential savings. Demonstration, documentation of performance and cost savings, and information dissemination are necessary to convince truck manufacturers, fleets, and operators of the benefits of idle reduction technologies. The EPA has projects underway to demonstrate offboard TSE, so, to avoid duplication of effort, the AVTA will focus on onboard idle reduction technology demonstration projects. Systems that use APUs (which provide electricity for heat, cooling, and other electrical accessories such as microwaves and laptop computers) are ideal candidates for this Demonstration Plan. However, DOE is interested in all onboard idle reduction strategies and has not eliminated any candidate technologies.

\section{Support for $21^{\text {st }}$ Century Truck Partnership}

The vision of the $21^{\text {st }}$ Century Truck (21CT) Partnership's is for our nation's trucks and buses to safely and cost-effectively move larger volumes of freight and passengers, while emitting little or no pollution and reducing U.S. dependence on foreign oil. The partnership's strategic approach includes promoting development and deployment of technologies that substantially reduce energy consumption and exhaust emissions during idling. Specific idle reduction technology goals are to:

- Develop and demonstrate by 2007 a commercially viable $5 \mathrm{~kW}, \$ 200 / \mathrm{kW}$, diesel-fueled internal combustion engine APU (0.2 diesel fuel g/hr, 200 lbs. weight; $0.5 \mathrm{cu}$. meter size; 65 decibels noise level; meets emission standards; integrates cooling and fueling systems; and meets the noise, vibration, harshness (NVH) requirements of the prime mover).

- Develop and demonstrate a commercially viable fuel cell APU system in the 5-30 kW range capable of operating on diesel fuel at a delivered cost of $\$ 400 / \mathrm{kW}$ by 2012.

In support of the 21CT Partnership, AVTA idle reduction demonstration projects will benchmark current idle reduction technology options and lay the groundwork for future demonstrations by identifying viable partners and methods. The AVTA demonstration projects will also provide data to baseline the present onboard idle reduction technology options, identify any necessary technology improvements, and focus $21 \mathrm{CT}$ development activities on idle reduction technologies that will have the greatest impact on idle reduction acceptance and utilization. The demonstration results and information collected (including driver behavior) will help define the criteria most important for fleet and driver acceptance. The Government and Industry teams formed to carry out the AVTA demonstration of currently available idle reduction technology options will establish the experience and methodology necessary for future successful idle reduction technology demonstrations.

\section{DOE Solicitation}

DOE intends to issue a solicitation requesting proposals to demonstrate and evaluate idle reduction technology. DOE anticipates awarding projects to fleets or owner-operators assembled into teams with support from truck and idle reduction technology manufacturers. All onboard idle reduction technologies will be considered, but the technologies and projects with the greatest impact will be chosen first. Projects with the greatest impact will use available idle reduction technology and have the highest probability of integration at the truck manufacturer level.

To meet the objectives of this project, the Demonstration Plan consists of five phases:

Phase 1: Initial needs assessment (completed early 2003)

Phase 2: Workshop for industry input (completed April 2003)

Phase 3: Solicitation and award of demonstration projects (mid 2003)

Phase 4: In-use evaluations (late 2003/early 2004)

Phase 5: Data analysis and dissemination (late 2004) 


\section{Phase 1 - Initial Needs Assessment}

The purpose of the initial needs assessment was to characterize operational needs and barriers to the use of idle reduction technologies in the heavy-duty truck fleet through discussions and interviews with industry representatives. This phase was completed in February 2003. Additionally, these interviews were used to gauge and document respondents' interest in participating in demonstration projects. Industry representatives include fleet managers, independent owner-operators, truck manufacturers, and idle reduction technology manufacturers. Participants in the needs assessment included members of the American Trucking Associations (fleet managers), members of the Owner-Operator Independent Drivers Association (owner-operators), truck manufacturers (Freightliner, Mack, PACCAR, Volvo), and many idle reduction technology manufacturers. This section features the results of the needs assessment.

\section{Operational Needs}

The information obtained from fleet managers and owner-operators indicates that the strongest interest (nearly $75 \%$ in both cases) in idle reduction technology is for systems that provide combined heating, cooling, and electricity. This interest stems from the fact that most trucks are operated in multiple areas of the country or areas that experience seasonal climatic changes. Interest in cooling or heating systems alone, a distant second in response, seems to only apply to trucks operating exclusively in northern (for heating) or southern (for cooling) climates.

About $50 \%$ of responding fleet managers track idle time and nearly $50 \%$ claim to use idle reduction systems or techniques. Only $17 \%$ of owner-operators questioned track idling and $16 \%$ use idle reduction systems. The principal reason owner-operators and fleets use idle reduction technologies is economicmore than $90 \%$ of the respondents report saving fuel as a principal reason. Of those that use or have tried idle reduction technologies, more than half report a good experience with reduced idle time, increased fuel economy, and reduced engine maintenance.

\section{Barriers}

Owner-operators report that the primary barriers facing idle reduction technologies are cost, reliability, maintenance requirements, and weight. Fleet managers report similar results but add that driver education, training, and receptiveness are notable barriers. Truck manufacturers also note that stronger interest in and pull for idle reduction technologies from fleet customers are necessary to further adopt and implement idle reduction technologies.

Cost is by far the biggest barrier with more than half of owner-operators and fleets reporting it as the number-one barrier to implementation. On average, fleets require a payback period of two years. Owneroperators allow a slightly longer period of two to three years, whereas truck original equipment manufacturers (OEMs) look at one year to 18 months for installed accessories. Typical calculations of savings are currently based only on fuel savings and do not include potential maintenance and engine life savings or possible increased resale values. According to idle reduction technology manufacturer data, idle reduction systems save $\$ 1,500$ to $\$ 2,000 / \mathrm{yr}$ in fuel costs. Typical combined heating, cooling, electrical systems cost $\$ 5,000$ to $\$ 7,000$. As such, their payback period is roughly two-and-a-half to four years. Truck manufacturers indicate fuel savings and reduced maintenance, and extended engine life could be measured via fleet operations using onboard data recording.

Lack of driver education, training, and receptiveness to idle reduction technologies constitutes the second largest barrier category reported by fleet managers. In fact, this issue ranked as the number-one barrier by $32 \%$ of respondents. Fleet managers felt truck operators idle because they are unaware of the benefits of reduced idling or out of habit. Teaching drivers the importance and benefits of reducing idling is critical to making a case for idle reduction technology use. 
Maintenance and reliability requirements, or service intervals for the installed idle reduction technology, should match those of the truck. idle reduction technologies may require basic maintenance (oil and filter changes) every month or two, but the fleet minimum maintenance schedule for trucks and engines is 13,000 miles or about every three months. However, owner-operators have indicated that the vast majority of operators do maintenance on their trucks every month or two, eliminating the need for additional idle reduction-specific maintenance. Truck life is about 10 years and 1 million or more miles, but the life of idle reduction technology is typically three to seven years. However, large fleets and owner-operators typically keep vehicles only four to seven years, reducing some concern about the shorter idle reduction system life, except for trade-in or resale value of the equipment.

Weight for combined heating, cooling, and electrical idle reduction systems is about $300 \mathrm{lbs}$. to $400 \mathrm{lbs}$. According to truck manufacturers, idle reduction systems should not exceed $100 \mathrm{lbs}$. to minimize any reduction in cargo carrying capacity and could benefit from a U.S. Department of Transportation weight exemption. Owner-operators do consider weight to be an issue $(26 \%$ rank weight as the number-two barrier), but fleet managers do not (ranked eighth by 23\%).

\section{Findings}

An idle reduction technology demonstration will focus on addressing the barriers to implementation. The most significant barrier is the initial cost and resulting payback period, which currently is too long to make a strong business case for fleets. The cost-benefit ratio of idle reduction technologies can be improved by:

- Installing technologies on the factory production line

- Providing demonstrations to statistically quantify (to the satisfaction of fleet managers) the cost savings of idle reduction technologies through reduced maintenance and extended engine life, as well as reduced fuel use

- Making volume purchases

- Providing tax credits for idle reduction technologies and exclusion from the federal excise tax

According to some truck manufacturers, installing idle reduction technologies on the truck while it is on the factory production line could reduce initial system cost by approximately $\$ 1,000$ and allow for an increased residual book value upon trade-in. Demonstrating and quantifying these cost savings (in addition to fuel savings), reduced engine maintenance, and extended life, would encourage fleet managers to include these benefits in their payback calculations, thus improving the business case.

Maintenance and reliability can be at least partly addressed by factory certification and production line installation. This factory certification should improve parts quality, availability, maintenance, and service. Another area to be considered is extending the maintenance intervals of the idle reduction technologies to better match those of trucks.

A three-pronged approach to addressing the barriers to idle reduction technologies appears appropriate.

- Prong 1 should include fleet demonstrations to show economic advantages that emanate from fuel savings, maintenance reductions, and extended engine life, and to compile unbiased information on the performance and service of idle reduction technologies. These demonstrations are the focus of this plan.

- Prong 2 should focus on cost reduction measures including production line installation by OEMs, volume purchases, and other incentives. These measures should result from successful fleet demonstrations.

- Prong 3 would include research and development on various aspects of idle reduction technologies, such as weight reduction, as an activity separate from this Demonstration Plan. 


\section{Phase 2 - Workshop for Industry Input}

As part of this project, the idle reduction technology evaluation team conducted a workshop to solicit input from the trucking industry on the Demonstration Plan and review the framework for a solicitation for demonstration projects (as detailed in Phase 3). The Idle Reduction Technologies for Heavy-Duty Trucks Workshop was held on April 15, 2003, at the Philadelphia Marriott in Philadelphia, Pennsylvania. Participants included industry representatives from truck fleets, truck manufacturers, technology manufactures, trade associations, and government. See Appendices A and B for workshop results.

The goals and objectives for the workshop were to:

- Review the results of the Phase 1 needs assessment and analyze the Demonstration Plan.

- Review the requirements of the Idle Reduction Technology Demonstration and Information Dissemination solicitation. Input from the workshop was be used to finalize the request for proposal, issued in April 25, 2003.

- Prioritize data types that idle reduction technology demonstrations should seek to develop and recommend data collection protocols.

\section{Phase 3 - Solicitation and Award of Demonstration Projects}

The demonstration and evaluation solicitation is intended to demonstrate the installation cost, operational cost savings (if any), and other benefits or shortcomings of current idle reduction technology. The solicitation will require teams to propose a project that will install equipment onboard trucks that will operate in multiple locations with varying climates for one year. The onboard equipment shall provide stand-alone cabin heating and/or cooling and electricity for standard plug-in accessories (laptop computer, etc.). The teams should consist of a truck fleet or owner-operator, a truck manufacturer, and an idle reduction technology manufacturer to ensure successful implementation and demonstration of the complete onboard idle reduction system. Fleets that already have in-use idle reduction technology data will also be considered.

Cost-shared Federal Financial Assistance Agreements will be awarded based on review of the submitted proposals by the idle reduction technology evaluation team. In general, proposals will be evaluated against criteria for the technology chosen, fleet characteristics, experience of the project partners, data collection methods, and projects costs and cost share.

\section{Selection of Technology}

The proposed technology may provide heating, cooling, and electricity. All onboard idle reduction technologies will be considered, but the technologies and projects proposed with the greatest impact will be chosen first for demonstration and evaluation. Candidate selection criteria may include the following:

- Technology must be available for installation and demonstration.

- Manufacturers must be interested in and committed to developing and commercializing technology and participating in this project.

- Idle reduction technology must have the potential to significantly reduce in-vehicle engine idling/fuel consumption and emissions, taking into account the energy consumption, cost, and emissions of the idle reduction technology.

- Manufacturers of idle reduction technology should be willing to share costs.

- Market penetration of technology may be considered.

\section{Selection of Fleet}

Fleets must consist of company-owned trucks or a group of independent owner-operators. The fleet selection criteria may include:

- Fleet must show strong interest in participating. 
- Fleet should be willing to share costs.

- Fleet must provide appropriate characteristics for vehicle engine idle reduction potential, such as size of fleet, vocation, and location.

- Fleet should have experience with idle reduction technologies.

- Fleet must be interested in and able to provide required data collection.

- Fleet must be committed to operating, maintaining, and supporting idle reduction equipment.

- Fleet must have suitable trucks for retrofit (i.e., support from truck manufacturers) or buy trucks that will be equipped with idle reduction technologies by a participating truck OEM.

\section{Selection of Team}

The following criteria apply to teams proposing to conduct idle reduction technology evaluation projects:

- Previous team experience on truck or idling issues will be considered.

- Team should consist of a truck fleet, a truck manufacturer, and an idle reduction technology manufacturer.

- Team should be willing to share costs.

\section{Phase 4 - In-Use Evaluations}

The Idle Reduction Technology Demonstration and Evaluation Project will require a substantial data collection effort. Once the onboard idle reduction system has been installed, and vehicles enter revenue service, operational data must be collected on demonstration and control vehicles (without idle reduction technology) for comparison. The demonstration project data needs are identified in Table 4 . The specifics of how the data are actually recorded and collected will be proposed by the bidders/participants and will be finalized after discussion with the fleet representative and the drivers involved. The program will attempt to integrate these efforts with other ongoing fleet data collection efforts by team members in the simplest and most cost-effective manner possible.

Automated data collection is preferred. For example, it is preferable to keep an automatic run-time log on the idle reduction technology instead of having the driver manually record when and for how long the device operates. During the data acquisition phase, the demonstration team will periodically check on the data collection. Questions to consider include:

- Are the right data being collected?

- Are there better ways to collect the data?

- Are there alternative data that might be superior?

- Are the data behaving as expected?

Based on this review, course corrections may be made: At the end of the in-use evaluation phase, all the data will be assimilated, analyzed, and documented in a report by the idle reduction demonstration project team. Types of analyses will include a determination of actual costs and savings compared with advertised and predicted costs and savings. Also documented will be lessons learned on acquiring data from fleet operations and reliability of the technologies. Results from this effort will also be used to lay the groundwork for further demonstrations, presentations to industry and trade groups, etc. The team recognizes that this first demonstration effort constitutes a very small sample, and large extrapolations may be difficult if not unwise. The in-use evaluation will, however, provide some definitive real world data that can be used to answer certain questions, provide direction for future demonstration activities, and develop meaningful communication between truck owner-operators, manufacturers, technology providers, and the government. 
Table 4. Idle Reduction Technology Demonstration Data Items

\begin{tabular}{|c|c|c|}
\hline Type of Data & Frequency Recorded & Data Items \\
\hline \multicolumn{3}{|c|}{ Idle Reduction Technology Specifications and Initial Costs } \\
\hline Idle Reduction System Descriptions & $\begin{array}{l}\text { Start of data collection and } \\
\text { changes as needed }\end{array}$ & Detailed description of installed system \\
\hline Idle Reduction System Capital Cost & $\begin{array}{l}\text { Start of data collection and } \\
\text { changes as needed }\end{array}$ & Total cost for IR system \\
\hline $\begin{array}{l}\text { Idle Reduction System Installation } \\
\text { Costs }\end{array}$ & $\begin{array}{l}\text { Start of data collection and } \\
\text { changes as needed }\end{array}$ & $\begin{array}{l}\text { Cost of installation including: labor time } \\
\text { and rate, and travel time to shop }\end{array}$ \\
\hline \multicolumn{3}{|c|}{ Vehicle Operation } \\
\hline Vehicle Operating Cycle & $\begin{array}{l}\text { Start of data collection and } \\
\text { changes as needed }\end{array}$ & $\begin{array}{l}\text { General description of daily use of } \\
\text { vehicles, more detailed information if } \\
\text { available }\end{array}$ \\
\hline \multirow{2}{*}{$\begin{array}{l}\text { Idle Reduction System Usage in } \\
\text { Service }\end{array}$} & \multirow[t]{2}{*}{ Each time IR system is used } & Start and stop time \\
\hline & & Purpose of idle time \\
\hline Fuel Use at Idle & Start of data collection & $\begin{array}{l}\text { Parasitic brake horsepower and engine } \\
\text { RPM at various load combinations }\end{array}$ \\
\hline \multirow[t]{4}{*}{ Fuel Consumption } & \multirow[t]{3}{*}{ Each time a vehicle is fueled } & Amount of fuel \\
\hline & & Odometer reading \\
\hline & & Date \\
\hline & $\begin{array}{l}\text { Each time the fuel price changes } \\
\text { at a given site }\end{array}$ & Price per unit \\
\hline Noise Level & Start of data collection & $\begin{array}{l}\text { Standardized decibel measurements } \\
\text { taken at various load conditions }\end{array}$ \\
\hline \multirow{8}{*}{$\begin{array}{l}\text { Engine Oil Consumption, Analysis } \\
\text { and Changes }\end{array}$} & \multirow[t]{3}{*}{ Each time oil is added } & Amount of oil \\
\hline & & Odometer reading \\
\hline & & Date \\
\hline & At regular service intervals & Oil analysis \\
\hline & \multirow{4}{*}{$\begin{array}{l}\text { Each time oil is changed as } \\
\text { recommended by the engine } \\
\text { manufacturer }\end{array}$} & Price per quart \\
\hline & & Amount of oil \\
\hline & & Odometer reading \\
\hline & & Date \\
\hline \multirow{10}{*}{$\begin{array}{l}\text { Maintenance (include maintenance } \\
\text { costs not only for IR technologies, } \\
\text { but for items like injectors, turbo- } \\
\text { charger seals, battery life, } \\
\text { alternators, fan clutch, AC } \\
\text { compressor, etc. that may be } \\
\text { reduced due to the use of IR } \\
\text { technologies) }\end{array}$} & \multirow[t]{10}{*}{ For each work order } & $\begin{array}{l}\text { Type of maintenance: scheduled, } \\
\text { unscheduled, road call, configuration } \\
\text { change }\end{array}$ \\
\hline & & Labor hours \\
\hline & & Date of repair \\
\hline & & Number of days out of service \\
\hline & & Odometer reading \\
\hline & & Parts replaced \\
\hline & & Parts cost \\
\hline & & Description of reported problem \\
\hline & & Description of repair performed \\
\hline & & $\begin{array}{l}\text { Typical data on maintenance costs for } \\
\text { trucks that do not use IR technologies }\end{array}$ \\
\hline \multicolumn{3}{|c|}{ Other Information Needed Evaluate IR Technology } \\
\hline \multirow[t]{2}{*}{ Fuel consumption of the IR device } & \multirow[t]{2}{*}{ Start of data collection } & Amount of fuel (for various loads) \\
\hline & & Operation time (duty cycle) \\
\hline Truck Emissions at Idle & Start of data collection & $\begin{array}{l}\text { Record historical or engine manufacturer } \\
\text { data }\end{array}$ \\
\hline IR Technology Emissions & Start of data collection & Record data from technology OEM \\
\hline Resale Value & End of demonstration & Value of vehicle \\
\hline Driver Satisfaction & $\begin{array}{l}\text { Quarterly and at end of } \\
\text { demonstration }\end{array}$ & $\begin{array}{l}\text { Record impressions and observations of } \\
\text { driver }\end{array}$ \\
\hline
\end{tabular}




\section{Phase 5 - Data Analysis and Dissemination}

The initial needs assessment (Phase 1) identified some key barriers to implementing IR technologies. These barriers included initial equipment cost, driver receptiveness, and equipment reliability and maintenance. The strategy to overcome these barriers is twofold: 1) demonstration and evaluation to address cost and technology, and 2) effective education and communication with the ultimate users to address driver receptiveness.

The results of the evaluation should quantify cost, reliability, and service barriers identified in the initial needs assessment as well as identify other possible issues with IR use. The evaluation must determine, document, and present the actual costs and savings associated with IR technology use as applied to several fleet applications. The evaluation report should examine the calculated payback period of initial costs and the corresponding business case to develop solutions for successful technology implementation. Regardless of the outcome of the evaluation, all results will be published, and these results will determine the next steps for the plan.

DOE will work with established information and training outlets to communicate the results of the project. Trucking firms, owner-operators, OEMs, and drivers will all need information about these technologies, each with a different point of view. To educate these ultimate users, information, data results, and reports must be communicated through all appropriate channels, including trade organizations and shows, major trucking organizations, and the Internet. DOE will disseminate and release information to trade media for inclusion in trade publications, the highest reported source of information on truck technologies for the trucking industry. 


\section{Appendix A}

U.S. Department of Energy Idle Reduction Technologies for Heavy-Duty Trucks Workshop 


\title{
U.S. Department of Energy Idle Reduction Technologies for Heavy-Duty Trucks Workshop
}

\author{
April 15, 2003 \\ Philadelphia, Pennsylvania
}

\begin{abstract}
The goal of this workshop was to solicit input and obtain feedback and guidance from industry to help tailor a request for proposals (RFP) for heavy-duty truck idle reduction technologies demonstration projects. This RFP was released by the U.S. Department of Energy (DOE) in late April 2003. The information has also been used to augment this Idle Reduction Technology Demonstration Plan. This plan lays the framework for demonstration and evaluation efforts to gather objective in-use information on the performance of idle reduction technologies by characterizing the cost; fuel, maintenance, and engine life savings; payback; and user impressions of various systems and techniques.
\end{abstract}

Specific objectives of the workshop were to (1) develop a prioritized list of data to be gathered during idle reduction technology demonstrations; (2) determine appropriate protocols for data collection; and (3) develop methods for estimating the economic value of engine wear and maintenance reductions that result from the use of idle reduction technologies.Following is a narrative synopsis of results and implications. Workshop results in raw, tabular form are provided following the synopsis in Appendix B.

\section{Data Collection and Protocols}

Return on investment is key for heavy-duty truck fleets to adopt idle reduction technologies. In general, fleets have indicated that a two-year payback period is needed for idle reduction technologies to be widely accepted commercially. The focus of the demonstrations should be to determine the differential between an idle reduction technology equipped truck and a standard truck, and should lead to identification of payback time for idle reduction systems. The ultimate objective is to accurately quantify savings via reduced fuel consumption and reduced maintenance expenses (the cost and time of maintenance for the idle reduction system is subtracted).

To avoid errors inherent with manual data collection, data should be collected with simple protocols that use information from the engine computer. Sample sizes should include 15-40 idle reduction equipped vehicles and a like number of control vehicles. An optimum target may be 15-25 idle reduction technology equipped vehicles to balance cost with a suitable sample size. Long-term evaluation is preferable, and testing should proceed for at least two full years to account for seasonal variations. Comparable and consistent testing methods should be used throughout, and one driver should, if possible, be used for each truck. Heavy-duty trucks generally travel more than 100,000 miles per year, and demonstration project participants should strive to achieve this threshold. The following discusses key data and protocols during heavy-duty truck idle reduction technology demonstration projects. See the tabular data in the preliminary workshop results document (dated April 24, 2003) for more detailed information.

A) Fuel Consumption: This is the most critical information. Despite past data collection efforts, there is still disagreement within the trucking industry about exactly how much fuel heavy-duty trucks consume during idling and how much idle reduction technologies consume. Demonstration participants must comprehensively, consistently, and accurately measure fuel consumption according to trucking industry standards. Fuel consumption data should be collected over the truck load/speed profiles (especially at idle) and for idle reduction technology (over load profile). Some workshop participants suggested that beaker tests should be conducted to maximize accuracy and that perhaps an outside testing entity should be involved to increase the validity of the measurements. The percentage of time spent idling, including the number of hours the idle 
reduction equipment is operated, should be closely monitored (both before and after installation). If possible, comparable routes should be traveled for idle reduction technology equipped and control vehicles.

B) Idle Reduction Technology Costs, Reliability, and Durability The purchase, installation, and maintenance costs of idle reduction technology should be documented. Installation includes the cost to retrofit the technology and, if possible, an estimate of the cost if the technology was installed on line at a truck OEM. Maintenance costs should track the reliability and durability of the system and should include regularly scheduled and unscheduled maintenance requirements. Truck downtime caused by the need to maintain idle reduction technologies should be closely tracked. When making calculations, regular failure costs of standard equipment should be substracted. Also, participants need to understand that the cost of repairing idle reduction systems may be higher because of small samples. Good record keeping is essential to fully illuminate maintenance issues.

C) Engine and Accessories Wear and Maintenance: Workshop participants agreed that idle reduction devices would extend the operating life of the truck's engine and that quantifying benefits from reduced idling would be ideal. However, fleet managers indicated that trucks are typically turned over every four years so fleets do not see the direct benefits of reduced engine wear in their cost calculations. Such a determination would require engines to be torn downs at about 700,000-1 million miles and 2 million miles, long after the demonstration programs are complete. The consensus was that fully quantifying the economic benefits of reduced engine wear within the framework of the proposed demonstration projects would not be feasible. However, reducing the number of engine operating hours is likely to increase the trucks' resale value.

Workshop participants agreed that quantifying the benefits of reduced accessory wear and replacement (injectors, turbo-charger seals, battery life, alternator, etc.) through the use of idle reduction devices is feasible. Cost avoidance due to redundant systems should also be tracked (e.g. alternators). Deferring oil and filter changes might also be feasible. Demonstration project participants should accurately track and quantify these secondary benefits.

D) Driver Acceptance: For idle reduction technologies to make a significant market impact, fleet managers and drivers must accept them. Data on driver acceptance, including drivers' perspectives on the reliability, features, comfort, and noise levels, should be collected. Tracking idle time and the number of overrides may provide good insight into driver acceptance, which should be captured through one standard survey. In this way, nuances that skew the results can be eliminated. Driver satisfaction must be assessed in corresponding areas both before and after the demonstration to provide an accurate baseline.

\section{General Comments}

Several workshop participants commented that a large body of data on idle reduction systems is already in place and should be tapped. The American Trucking Association, certain truck fleets, and idle reduction technology manufacturers have collected considerable data over a number of years. Participants felt funding should be used retroactively to examine engine wear and that oil change analyses should be benchmarked by hours of engine operation rather than vehicle miles traveled. Some also mentioned that DOE should be judicious when publishing information resulting from the demonstration projects because operating conditions and other assumptions could skew information. Only quantitative information should be published. 


\section{Appendix B}

Preliminary Workshop Results 
Idle Reduction Technologies for Heavy-Duty Trucks

April 15, 2003

Philadelphia, Pennsylvania

\section{Preliminary Workshop Results}

April 24, 2003 


\begin{tabular}{|c|c|}
\hline \multicolumn{2}{|c|}{ Breakout Session A Participants: } \\
\hline NAME & ORGANIZATION \\
\hline Paul Abelson & Land Line Magazine \\
\hline Mike Bacon & Webasto Product North America \\
\hline & RigMaster Power \\
\hline Dennis Damman & Schneider National, Inc. \\
\hline John Duffy & Kenworth \\
\hline Jim Francfort & INEEL/DOE \\
\hline Epi Gonyea & Aura Systems Inc. \\
\hline Rex Greer & Pony Pack, Inc. \\
\hline Eric Jessiman & Espar, Inc. \\
\hline Richard Nellums & Eaton Corporation \\
\hline David Orr & Caterpillar Inc. \\
\hline Michael Panich & ANTARES Group Inc. \\
\hline Patricia Passarella & U.S. DOE/Philadelphia \\
\hline Ken Proc & NREL \\
\hline Lee Slezak & U.S. DOE \\
\hline Ronald Szapacs & Air Products \& Chemicals Inc. \\
\hline Eldon Willis & Auxillary Power Dynamics \\
\hline
\end{tabular}


EXHIBIT 1. TYPeS of DATA IDLE REDUCTION to DEVELOP

$\diamond=$ MOST CRITICAL DATA TYPE

\begin{tabular}{|c|c|c|c|c|}
\hline Value Creation & $\begin{array}{c}\text { Driver } \\
\text { Acceptance }\end{array}$ & Pre and Post Data & $\begin{array}{c}\text { Ideal but } \\
\text { Infeasible }\end{array}$ & Notes \\
\hline
\end{tabular}

- Fuel consumption - this is the most critical data type to be collected, no voting required

- Payback time (cost per mile)

\section{$\diamond \diamond$}

- Differentials between idle reduction truck and standard truck

$\diamond \diamond \diamond \diamond$

- Reliability of system

- Initial costs

$\diamond \diamond$

- Based on retrofit or OEM

- Maintenance comparisons, analysis

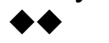

- Hours of engine use in 1) in motion, 2) not in motion, 3) still and hotel loads

$\diamond$

- Type of hotel loads being used

- Amount of alternative energy used

- Oil changes tracked by engine hour not engine miles

\begin{tabular}{|c|c|c|c|}
\hline $\begin{array}{l}\text { - Driver } \\
\text { acceptance } \\
\text { - Reliability } \\
\text { - Features } \\
\text { - Customer } \\
\text { experiences } \\
\text { including } \\
\text { comfort } \\
\text { levels } \\
\text { - Track by } \\
\text { reduction in } \\
\text { idle time } \\
\text { - Noise level }\end{array}$ & $\begin{array}{l}\text { - Loads and duty } \\
\text { cycles } \\
\text { - Establish an idling } \\
\text { standard definition } \\
\text { (could use the } \\
\text { definition in the } \\
\text { Energy Bill) } \\
\text { - Amount of energy } \\
\text { and resources } \\
\text { wasted by engine } \\
\text { idling } \\
\text { - Resources } \\
\text { associated with } \\
\text { oversized } \\
\text { engines } \\
\text { - Percentage of time } \\
\text { at full load (time } \\
\text { vs. load data) } \\
\text { - Driver incentive } \\
\text { plans } \\
\text { - Time required for } \\
\text { driver training on } \\
\text { idle reduction } \\
\text { technologies } \\
\text { - Levels of } \\
\text { emissions } \\
\text { TMC data on R } \\
\text { factor of cabs } \\
\text { - Fleet profile and } \\
\text { vehicle types }\end{array}$ & $\begin{array}{l}\text { - Operating } \\
\text { conditions } \\
\text { (ambient and } \\
\text { interior } \\
\text { temperatures, } \\
\text { region/route } \\
\text { history, noise, } \\
\text { etc.) }\end{array}$ & $\begin{array}{l}\text { - May require } \\
\text { tax } \\
\text { incentives, } \\
\text { etc. for idle } \\
\text { reduction } \\
\text { technologies } \\
\text { to become } \\
\text { broadly } \\
\text { accepted } \\
\text { - Value may } \\
\text { be found in } \\
\text { TMC efforts } \\
\text { that are } \\
\text { similar in } \\
\text { nature }\end{array}$ \\
\hline
\end{tabular}




\section{EXHIBIT 2. PRotocols to EnSURE DATA ARE ACCEPTED By INDUSTRY}

\begin{tabular}{|c|c|}
\hline DATA TYPE & DATA Protocols \\
\hline $\begin{array}{l}\text { Value Creation: } \\
\text { Fuel Consumption }\end{array}$ & $\begin{array}{l}\text { - Load versus speed charting fuel consumed } \\
\text { during engine idle and driving } \\
\text { - Quantify percent of idle time required before } \\
\text { and after idle reduction technology } \\
\text { installation to achieve desired payback } \\
\text { periods } \\
\text { - Quantify savings opportunities in states that } \\
\text { allow rebate of state/federal road tax for fuel } \\
\text { consumed by idle reduction technologies }\end{array}$ \\
\hline $\begin{array}{l}\text { Value Creation: } \\
\text { Hours of Engine } \\
\text { Use }\end{array}$ & $\begin{array}{l}\text { - Simple data collection protocol from engine } \\
\text { computer }\end{array}$ \\
\hline $\begin{array}{l}\text { Value Creation: } \\
\text { Initial Costs }\end{array}$ & - Purchase cost and installation costs \\
\hline ptance & $\begin{array}{l}\text { - Tracking idle time may reveal acceptance } \\
\text { (significant idle reduction may equate to } \\
\text { more acceptance) } \\
\text { - Conduct survey at end of the demonstration } \\
\text { to gauge driver acceptance ("would you do } \\
\text { this again with your own money?") } \\
\text { - Track number of operator overrides } \\
\text { - Note: system reliability is tied to acceptance }\end{array}$ \\
\hline $\begin{array}{l}\text { System Reliability } \\
\text { (Early Hour } \\
\text { Unreliability) }\end{array}$ & $\begin{array}{l}\text { - Cost for repairs (including downtime cost) } \\
\text { due to malfunctions } \\
\text { - This quantifies the cost of technology } \\
\text { failure } \\
\text { - May be susceptible to low sample size } \\
\text { issues } \\
\text { - Subtract regular failure costs of standard } \\
\text { equipment } \\
\text { - Cost avoidance in other systems due to } \\
\text { redundant systems (e.g., alternators) } \\
\text { - Jump starts/road service calls }\end{array}$ \\
\hline $\begin{array}{l}\text { Maintenance } \\
\text { Comparisons and } \\
\text { Analysis }\end{array}$ & $\begin{array}{l}\text { - Time and cost for maintaining idle reduction } \\
\text { system } \\
\text { - Frequency of oil changes }\end{array}$ \\
\hline
\end{tabular}


EXHIBIT 3. Possible Methods for Assigning Economic Value to Reduced Wear/Maintenance Resulting fRom IDLE Reduction TeChNologies

- Reduced number of engine hours may increase resale value

- This may be particularly relevant for owneroperators

- Wear and maintenance costs for accessories may decrease because of shorter idle time

- E.g., injectors, turbocharger seals, battery life, alternator life, fan clutch, starting

- Deferred oil changes (conduct oil analysis)

- Engine tear-downs at 1 million and 2 million miles may reveal engine wear savings

- Highly dependent on fleet profile

- Use published surveys (TMC) subtract fuel to determine additional savings 


\begin{tabular}{|c|c|}
\hline \multicolumn{2}{|c|}{ Breakout Session B Participants: } \\
\hline NAME & ORGANIZATION \\
\hline Ken Adams & Javic Transportation \\
\hline Michael Anderson & U.S. DOE - Idaho Operations \\
\hline Roger Collins & Auxiliary Power Dynamics \\
\hline John Dennehy & Espar Heater Systems \\
\hline Linda Gaines & Argonne National Laboratory \\
\hline Klaus Holze & TruckGen \\
\hline Donald Kanneth & Webasto Product North America \\
\hline Steven Kohl & Transport Corp. of America \\
\hline Heather McKee & U.S. Army TACOM NAC \\
\hline Robert Nitschke & INEEL \\
\hline Thomas Perrot & ANTARES Group Inc. \\
\hline Paul Richards & Commercial Carrier Journal \\
\hline Karl Rojc & Aura Systems Inc. \\
\hline Al Smith & Teleflex (Proheat) \\
\hline George Strickland & Travel Centers of America \\
\hline Victor Suski & American Trucking Association \\
\hline Fred Wagner & Energetics, Inc. \\
\hline Skip Yeakel & Volvo Trucks North America \\
\hline
\end{tabular}




\section{EXHIBIT 4. TyPES OF DATA to DEVELOP}

$\diamond=$ Most CRITICAL DATA TYPE

\begin{tabular}{|c|c|c|c|}
\hline $\begin{array}{c}\text { ACQUISITION COSTS } \\
\text { AND SPECS }\end{array}$ & OPERATING COSTS & OWNERSHIP COSTS & $\begin{array}{c}\text { Other Evaluation } \\
\text { DATA }\end{array}$ \\
\hline $\begin{array}{l}\text { - Idle reduction } \\
\text { system capital } \\
\text { cost } \\
\text { - Idle reduction } \\
\text { system } \\
\text { installation costs } \\
\text { - Idle reduction } \\
\text { system } \\
\text { descriptions } \\
\text { - Weight }\end{array}$ & $\begin{array}{l}\text { - Fuel use at idle } \\
\text { - Vuel consumption } \\
\text { - Idle reduction system } \\
\text { usage in service } \\
\text { (hours/\%) }\end{array}$ & $\begin{array}{l}\text { - Maintenance } \\
\text { - Other component } \\
\text { lifetimes } \\
\text { (alternators, etc.) } \\
\text { - Engine oil } \\
\text { consumption and } \\
\text { changes }\end{array}$ & $\begin{array}{l}\text { - User satisfaction } \\
\text { - Truck emissions at } \\
\text { technology } \\
\text { emissions } \\
\text { - Resale value } \\
\text { - Temperature } \\
\text { operated in } \\
\text { - Routes traveled } \\
\text { - Comparable } \\
\text { routes for both } \\
\text { idle reduction and } \\
\text { control vehicles } \\
\text { - Engine overhaul } \\
\text { costs }\end{array}$ \\
\hline
\end{tabular}

Other discussion items of interest:

- Customer weight demands sometimes limit application of idle reduction technologies

- Fleets generally dictate to OEMs what they want on their trucks

- $90+\%$ of trucks owned by fleets with fewer than 20 trucks

- Industry publication expected to start providing resale value for trucks with different idle reduction technologies installed 


\section{EXHiBIT 5. PRotocols to ENSURE dATA ARE ACCEPTED By INDUSTRY}

$\checkmark=$ MOST IMPORTANT PROTOCOL

\begin{tabular}{|c|c|c|c|c|c|}
\hline \multicolumn{4}{|c|}{ Data Collection } & \multicolumn{2}{|r|}{ Demo PARAmEters } \\
\hline User SATISFACtion & $\begin{array}{l}\text { FUEL USE AT } \\
\text { IDLE }\end{array}$ & $\begin{array}{l}\text { IDLE REDUCTION FUEL } \\
\text { CONSUMPTION }\end{array}$ & MAINTENANCE & $\begin{array}{c}\text { SAMPLE } \\
\text { SIZE* } \\
\text { (IDLE } \\
\text { REDUCTION } \\
\text { AND } \\
\text { CONTROL } \\
\text { EACH) }\end{array}$ & LENGTH AND REPORTING \\
\hline $\begin{array}{l}\text { - Require a } \\
\text { standard survey } \\
\text { - Assess } \\
\text { satisfaction } \\
\text { before and after } \\
\text { demonstration } \\
\text { - Education/training } \\
\text { - Operator controls }\end{array}$ & $\begin{array}{l}\text { - RPM } \\
\text { measure- } \\
\text { ment } \\
\text { - Beaker } \\
\text { tests } \\
\text { SAE-3 } \\
\text { (only } \\
\text { rolling } \\
\text { currently) }\end{array}$ & $\begin{array}{l}\text { - Outside testing } \\
\text { - Number of hours } \\
\text { idle reduction } \\
\text { equipment } \\
\text { operated } \\
\text { - Uptime/downtime/\$ } \\
\text { - Flowmeters or } \\
\text { separate tank } \\
\text { - Vehicle operating } \\
\text { data } \\
\text { - Use SAE } \\
\text { standard? }\end{array}$ & $\begin{array}{l}\text { - Ensure good } \\
\text { record } \\
\text { keeping } \\
\text { - Capture and } \\
\text { distinguish } \\
\text { scheduled, } \\
\text { unscheduled } \\
\text { maintenance } \\
\bullet \bullet \\
\text { Capture } \\
\text { second } \\
\text { order } \\
\text { benefits if } \\
\text { possible } \\
\bullet\end{array}$ & $\begin{array}{l}\cdot \text { Less } \\
\text { than } 15 \\
\text { - } 15-25 \\
\text { - } 25-40 \\
-\leftrightarrow \leftrightarrow< \\
-40-60 \\
\text { - } 60+\end{array}$ & $\begin{array}{l}\text { - Two full seasons } \\
\text { - Interim } 1 \text { year report } \\
\text { - Preliminary } \\
\text { assessment of } \\
\text { technology after a few } \\
\text { months } \\
\text { - Long-term evaluation } \\
\text { desirable } \\
\text { - Minimum number of } \\
\text { miles traveled } \\
\text { - Single driver } \\
\text { throughout demo } \\
\text { - Comparable/consistent } \\
\text { testing methods, } \\
\text { requirements }\end{array}$ \\
\hline
\end{tabular}

* Each participant was required to vote for one sample size from the five choices

Other discussion items of interest:

- Department of Transportation has used sample sizes of 50 for some applications (e.g., tire testing)

- Some existing technology demonstrations are using sample sizes of 100 in existing fleets; while others are using 30

- EPA has published data from a controlled, off-road test, including:

- Fuel

- Emissions

- Idea was raised as to whether a single fleet should evaluate multiple technologies (e.g., 10 technologies)

- R.O.I. is key for adoption

- Drivers often not currently required to use the idle reduction technology installed on their trucks. How can incentives ensure use of the installed idle reduction technology? 


\section{REPORT DOCUMENTATION PAGE}

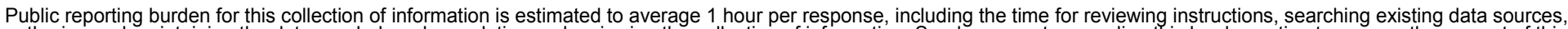

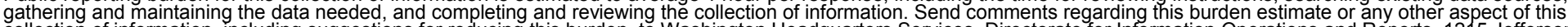

ation including suggestions for reducing this burden, to Washington Headquarters Services, Directorate for Information Operations a

Davis Highway, Suite 1204, Arlington, VA 22202-4302, and to the Office of Management and Budget, Paperwork Reduction Project (0704-0188), Washington, DC 20503.
1. AGENCY USE ONLY (Leave blank)
2. REPORT DATE
September 2003
3. REPORT TYPE AND DATES COVERED Technical Report
4. TITLE AND SUBTITLE
Idle Reduction Technology Demonstration Plan
6. $\mathrm{AUTHOR}(\mathrm{S})$
Ken Proc, NREL; Bob Nitschke, INEEL; Fred Wagner, Energetics; Mike Anderson, DOE; Lee Slezak, DOE

5. FUNDING NUMBERS

FC03.0730

7. PERFORMING ORGANIZATION NAME(S) AND ADDRESS(ES)

8. PERFORMING ORGANIZATION REPORT NUMBER

9. SPONSORING/MONITORING AGENCY NAME(S) AND ADDRESS(ES)

National Renewable Energy Laboratory

1617 Cole Blvd.

Golden, CO 80401-3393

AGENCY REPORT NUMBER

NREL/TP-540-33629

11. SUPPLEMENTARY NOTES

NREL Technical Monitor: Leslie Eudy

12a. DISTRIBUTION/AVAILABILITY STATEMENT

National Technical Information Service

12b. DISTRIBUTION CODE

U.S. Department of Commerce

5285 Port Royal Road

Springfield, VA 22161

13. ABSTRACT (Maximum 200 words)

The purpose of the Demonstration Plan is to define a pathway to idle reduction technology implementation and use by addressing these issues. The intended outcome of this demonstration and evaluation is to identify and remove barriers for the targeted use of idle reduction technologies in trucking applications. Positive results will encourage truck operators to demand these systems and motivate truck manufacturers to integrate and install idle reduction as standard equipment.

Idle reduction technology; heavy-duty trucks; evaluation; fleet; demonstration plan

15. NUMBER OF PAGES

16. PRICE CODE

17. SECURITY CLASSIFICATION OF REPORT

Unclassified
18. SECURITY CLASSIFICATION OF THIS PAGE Unclassified
19. SECURITY CLASSIFICATION OF ABSTRACT

Unclassified
20. LIMITATION OF ABSTRACT

UL 